\title{
Research on the Impact of Internet Finance on the Efficiency of Chinese Commercial Banks
}

\author{
Shuo Zhao \\ College of Economics, Jinan University, Guangzhou, China \\ Email: zhaoshuo19940806@163.com
}

How to cite this paper: Zhao, S. (2018) Research on the Impact of Internet Finance on the Efficiency of Chinese Commercial Banks. American Journal of Industrial and Business Management, 8, 898-911. https://doi.org/10.4236/ajibm.2018.84062

Received: March 23, 2018

Accepted: April 24, 2018

Published: April 27, 2018

Copyright $\odot 2018$ by author and Scientific Research Publishing Inc. This work is licensed under the Creative Commons Attribution International License (CC BY 4.0).

http://creativecommons.org/licenses/by/4.0/

Open Access

\begin{abstract}
This paper selects 15 Chinese commercial banks as the research sample, using stochastic frontier approach, setting Trans-log Production Function. The paper firstly measures the efficiency of commercial banks, and the results show that the efficiency level of Chinese commercial banks is on the rise from 2007 to 2016, and the efficiency of state-owned banks is higher than that of joint-stock banks. Secondly, the paper studies the influence factors of the efficiency of Chinese commercial banks in the view of banks' own factors, industry factors, Internet financial development factors. The results show that the non-performing loan ratio level and the Internet financial development are negatively related to the bank efficiency, and competition of market is positively associated with the bank efficiency, and the structure of property rights will also significantly affect the performance of commercial banks.
\end{abstract}

\section{Keywords}

Bank Efficiency, Internet Finance, Third-Party Payment

\section{Introduction}

The financial industry plays a vital role in Chinese economic development, and commercial banks occupy an absolutely important position in the financial system. The data from China Banking Regulatory Commission and National Bureau of Statistics of China show that, the credit balance of the banking sector accounts for over $90 \%$ of the credit balance of financial institutions. The increment of social financing in China was 194,443 billion yuan, and RMB loans were 138,432 billion yuan, accounting for $71.2 \%$ of the increment in social financing. And by the end of 2016, the total assets of the banking financial institutions were 232.3 trillion yuan, accounting for $312 \%$ of the total GDP of 2016. The asset size has increased by $341 \%$ over 2007. At present, China's banking system has five 
national commercial banks, 12 joint-stock commercial banks, 134 city commercial banks, 1114 rural commercial banks, and 8 private banks. The number of commercial banks is increasing, the scale of banking system is expanding, and the industrial structure is becoming more and more diversified.

The efficiency level of commercial banks reflects the banks' comprehensive management ability, risk prevention ability, asset management level and profitability. Under the subtle influence of Internet finance, China's financial efficiency and even the whole financial structure are undergoing tremendous changes. In order to realize rapid and steady development, traditional financial institutions need to look at their own problems, and face the competition of Internet finance in development vision, and properly handle the relationship with the Internet finance.

The aim of the paper is to examine the determinants of efficiency in Chinese banking system over the period 2007-2016. In this paper, we choose the loanable funds, labor force and fixed assets as input indicators, total loan, interest income and non-interest income as output indicators, and add the loan loss reserves as a risk factor. We measure the efficiency value of commercial banks by the SFA model based on translog production function, and research the relationship between bank efficiency and the Internet financial development, bank's own factors, industry factors. And then we put forward some suggestions on the improvement of commercial banks' efficiency based on the results of empirical analysis.

The structure of the paper is following. Next chapter presents empirical literature. Third section describes methodology (stochastic frontier approach). Section 4 presents data and selection of variables and the efficiency measurement results. The fifth section shows empirical analysis of determinants of bank efficiency. The last section concludes this paper.

\section{Empirical Literature}

Scholars have found that commercial banks' own characteristics and external environment will have an impact on the bank efficiency. Foreign scholars and domestic scholars have different research priorities. Foreign scholars mainly focus on the influence of industry factors on bank efficiency, such as market structure and banking competition, while domestic scholars mostly study the bank's own characteristics and macroeconomic factors. Few scholars directly study the impact of internet finance on bank efficiency. However, more and more scholars begin to study the relationship between internet finance and commercial bank management, which will also provide some reference for the paper.

\subsection{Literature Review on Influence Factors of Bank Efficiency}

Domestic and foreign empirical analysis shows that the characteristics of commercial banks and the external environment will affect the efficiency of banks. Foreign scholars and domestic scholars have different research emphasis, and 
foreign scholars generally choose market structure and banking competition degree as the key point, while domestic scholars put more emphasis on the characteristics of commercial banks and macroeconomic factors.

IvetaŘepková (2015) studied the inefficiencies of the Czech banking industry from 2001 to 2012. It was found that ROA, interest rate and GDP had a negative effect on Czech bank's efficiency, while bank asset size, liquidity risk and portfolio risk have positive effect on Czech bank efficiency [1]. Yong Tan, Christos Floros (2013) choose 101 Chinese commercial Banks as samples, investigated the impact of risk and capital structure on the efficiency of banks, and the empirical results show that the loan loss reserve ratio and the bank liquidity and asset scale were positively correlated to the bank efficiency, bank assets was associated with a significant banking market concentration degree, the bank asset size is significantly correlated with the concentration of banking market [2]. Aida Mosko, Anilda Bozdo (2016) chose 16 Banks in Albania in 2002-2014 as samples, studied the relationship between risk, capital structure and bank efficiency using the three-stage DEA model. The empirical results show that there are inefficiencies in Albania banking system, strengthening capital regulation will reduce bank's risk exposure, higher capital requirements will reduce the risk of moral hazard, which will enhance the level of bank efficiency, thereby improve the stability of the Albania financial system [3].Franco Fiordelisi, David Marques-Ibanez, Phil Molyneux (2011) took 153 commercial Banks in Europe in 1995-2007 as sample, studied the relationship between risk, capital structure and bank efficiency with the Granger causality test, the empirical results show that the high efficiency of the bank leads to the optimization of capital structure, and the good capital structure also has a positive effect on the bank's efficiency level, while the lower efficiency of the bank tends to increase the risk of the bank [4]. Manthos Delis, Maria Iosifidi, Mike G Tsionas (2017) took the data of 419 banks in the United States from 1976 to 2014 as samples, the risk is defined by the variance of the bank's net income, and introduced the risk into the bank efficiency measurement model. Research showed that ignoring risk factors will result in significant deviations in bank efficiency estimates [5].

Wang Cong, Zou Pengfei (2006) took the impact of capital structure and risk factors on the efficiency of commercial Banks into consideration, used SFA to estimate the cost efficiency of China's commercial banks. The research shows that the efficiency of listed banks in China is the best, followed by the non-listed banks, the efficiency of the state-owned banks is the worst, and the capital structure and risk situation significantly affect the efficiency of commercial banks and the rank of efficiency [6]. Cheng Maoyong (2011) chose 64 commercial banks in China from 2000 to 2009 as the research sample. Firstly, he measured the market power of commercial banks by Lerner index, and then explored the correlation between the market forces and bank efficiency. The empirical shows that there is a significant linear relationship between market forces and bank efficiency, the stronger the market forces is, the lower the cost efficiency is and the higher the profit efficiency is [7]. Liu Ruixiang, Lv Daxue, Lue Yi (2016) 
considered the impact of the Non-performing loan on bank efficiency with the Improved two-stage DEA model, the empirical shows that the Non-performing loans have a significant impact on the efficiency value of joint-stock banks, and have little impact on the efficiency of the four state-owned banks [8]. He Yong (2014) found that the money supply is positively correlated with the cost efficiency of commercial banks, while the impact of GDP and CPI on commercial banks' efficiency is not significant by analyzing the influence factors of the efficiency of commercial banks in China from 2008 to 2013 [9].

\subsection{Literature Review on Internet Finance and Banking Efficiency}

Domestic and foreign scholars have little research on Internet finance and banking efficiency. Domestic scholars have not agreed on a conclusion about the relationship between internet finance and the traditional banks. Some scholars think that there is a competitive relationship between the internet finance and the traditional banks. They think that the internet finance has an impact on commercial banks to some extent, but in general, the impact is not particularly large. Zhu Jinchuan (2013) believed that Internet finance has a certain impact on commercial banks in the short term. Then the empirical analysis proves that Internet finance has a certain impact on traditional financial institutions, but the scope and extent of impact are limited [10]. Qiu Feng (2013) studied the impact of Internet finance on commercial banks and found that the Internet finance can't shake the status of traditional commercial banks temporarily. Given the disadvantages of Internet finance and the special status of traditional commercial banks, there are competition and cooperation relationship between them [11]. Zhang Meng (2014) believed that the areas where Internet finance is currently involved are concentrated in areas where traditional commercial banks are trying to develop, which is complementary to the business of traditional commercial banks [12]. Therefore, the impact of Internet finance on traditional banks in terms of market size is not particularly strong in the short term. However, some other scholars believed that the development of Internet finance had a profound impact and great shock on the traditional commercial banks. They thought that the Internet financial has a lot of advantages, such as more convenient payment, lower transaction costs, more efficient allocation of resources and higher transparency, which will have a comprehensive, persistent and systematic impact on the traditional commercial banks.

\section{Methodology}

Battese \& Coelli (1995) proposed stochastic frontier approach to study bank efficiency in 1995, this approach assumes that the inefficiency items are non-negative, it obey truncated normal distribution and independent distribution. The inefficiency items can be represented as functions of a series of internal and external variables and its mean is a linear function of the correlated variables. Generally, the Battese \& Coelli (1995) model is showed as follows [13]: 


$$
\begin{gathered}
\ln y_{i t}=\beta_{0}+\beta_{t} t+\beta x_{i t}+\ln v_{i t}+\ln u_{i t}, i=1, \cdots, N ; t=1, \cdots, T \\
m_{i t}=\delta_{0}+\delta_{t} t+\delta z_{i t}+W_{i t} \\
C E_{i t}=\exp \exp \left(u_{i t}\right)=\exp \exp \left(z_{i t} \delta+W_{i t}\right) \\
T E_{i t}=\exp \exp \left(-u_{i t}\right)=\exp \exp \left(-z_{i t} \delta-W_{i t}\right)
\end{gathered}
$$

Equation (1) is the profit frontier model, where, $i$ represents the bank, $t$ represents the time, $\ln y_{i t}$ represents the cost or profit of the bank in a logarithmic form, $X_{i t}$ represents the input and output of bank " $\vec{i}$ in " $i$ " year. $v_{i t}$ and $u_{i t}$ are assumed to be independently distributed. $V_{i t}$ is a random variable, which is a normal distribution with zero mean and variance $\sigma_{v}^{2} \cdot u_{i t}$ is positive and obtained by truncation at zero of the normal distribution with mean $m_{i t}$ and variance $\sigma_{v}^{2} \cdot \beta$ is parameters to be estimated.

Equation (2) is the inefficiency items, where $z_{i t}$ is a variable which is composed of a series of influencing factors related to enterprise inefficiency. $W_{i t}$ is a random variable with zero mean and variance $\sigma^{2} . \delta$ is parameters to be estimated.

Equation (3) is the calculation formula of cost efficiency and profit efficiency.

Whether the stochastic frontier approach can be used to judge the estimation results depends on two key factors. The null hypothesis test result of $\gamma$ is the fundamental criterion for determining whether frontier profit function is effective, which determines whether the stochastic frontier approach can be used. The distribution of the inefficiency items $u_{i t}$ is also of vital importance. The maximum likelihood function estimation method (ML) is used for parameter estimation of stochastic frontier function. The difference between ML and ordinary least squares (OLS) is that OLS can only be estimated based on a given independent variable. The influence of measurement error and other uncontrollable factors cannot be considered comprehensively with OLS. While ML searches through two grid points to calculate the value of $\gamma$. ML use the unilateral likelihood ratio (LR) test to determine to reject the original hypothesis of gamma $=$ 0 or not and to judge the error is mainly affected by the random error term or the systematic influence of other variables other than the given independent variable. $\gamma$ represents the ratio of the inefficiency items to the total error, which is between 0 and $1 . \Gamma$ is used to determine the advantages and disadvantages of OLS and ML, and further determine whether to select stochastic frontier approach.

\section{Empirical Study on Bank Efficiency Measurement}

\subsection{Modeling, Data and Selection of Indicators}

1) Modeling

This paper is based on the Battes \& Coelli (1995) [13] model, and construct the risk bearing efficiency model by transcendental logarithm function with the research ideas of Fiordelisi et al. (2011) [4] and Yao Shujie (2011) [14].

Loan loss reserves is an expense set aside as an allowance for uncollected loans and loan payments. This provision is used to cover a number of factors asso- 
ciated with potential loan losses including bad loans, customer defaults and renegotiated terms of a loan that incur lower than previously estimated payments. It reflects the bank's credit risk situation to some extent. We can measure the bank efficiency more precisely by adding credit risk factors (Loan loss reserves) into Equation (1).

Take profit efficiency as an example, profit efficiency measurement model with risk consideration is as follow:

$$
\begin{aligned}
\ln P T A & =\alpha_{0}+\sum_{i=1}^{3} \alpha_{i} \ln y_{i}+\sum_{i=1}^{3} \beta_{i} \ln w+t_{1} T+\tau_{1} \ln R \\
& +\frac{1}{2}\left[\sum_{i=1}^{3} \sum_{j=1}^{3} \delta_{i j} \ln y_{i} \ln y_{j}+\sum_{i=1}^{3} \sum_{j=1}^{3} \gamma_{i j} \ln w_{i} \ln w_{j}+t_{11} T^{2}+\tau_{11} \ln R^{2}\right] \\
& +\sum_{i=1}^{3} \sum_{j=1}^{3} \rho_{i j} \ln y_{i} \ln w_{j}+\sum_{i=1}^{3} \sum_{j=1}^{3} \varphi_{i} \ln y_{i} T+\sum_{i=1}^{3} \sum_{j=1}^{3} \vartheta_{i} \ln w_{i} T \\
& +\sum_{i=1}^{3} \sum_{j=1}^{3} \theta_{i j} \ln y_{i} \ln R+\sum_{i=1}^{3} \sum_{j=1}^{3} \mu_{i j} \ln w_{i} \ln R+\sum_{i=1}^{3} \sum_{j=1}^{3} \pi_{i j} T \ln R-\ln u_{i t}+\ln v_{i t}
\end{aligned}
$$

where PTA represents pretax profit, $y_{i}$ represents output indicators: Total loan, interest income and non-interest income. $w_{i}$ represents the price of input indicators: the price of loanable funds, labor price and fixed asset price. $\mathrm{R}$ represents the Loan loss reserves, $T$ represents time trend, $V_{i t}$ is a random variable, which is a normal distribution with zero mean and variance $\sigma_{v}^{2} \cdot u_{i t}$ is positive and obtained by truncation at zero of the normal distribution with mean $m_{i t}$ and variance $\sigma_{v}^{2} \cdot \beta$ is parameters to be estimated.

In order to satisfy the linear homogeneous restriction of input indicators' price, we standardize the pretax profit and other input indicators with fixed asset price. In order to control the size bias and variance of banks, we standardize pretax profit and output indicators with total assets of banks.

According to the symmetry principle: $\delta_{i j}=\delta_{j i}, \gamma_{i j}=\gamma_{j i}$ and $\rho_{i j}=\rho_{j i}$, Equation (5) can be simplified as follows:

$$
\begin{aligned}
\ln \frac{P T A}{w_{3} * A}= & \alpha_{0}+\sum_{i=1}^{3} \alpha_{i} \ln \frac{y_{i}}{A}+\sum_{i=1}^{3} \beta_{i} \ln \frac{w_{i}}{w_{3}}+t_{1} T+\tau_{1} \ln R \\
& +\frac{1}{2}\left[\sum_{i=1}^{3} \sum_{j=1}^{3} \ln \frac{y_{i}}{A} \ln \frac{y_{j}}{A}+\sum_{i=1}^{3} \sum_{j=1}^{3} \gamma_{i j} \ln \frac{w_{i}}{w_{3}} \ln \frac{w_{j}}{w_{3}}+t_{11} T^{2}+\tau_{11} \ln R^{2}\right] \\
& +\sum_{i=1}^{3} \sum_{j=1}^{3} \rho_{i j} \ln \frac{y_{i}}{A} \ln \frac{w_{j}}{w_{3}}+\sum_{i=1}^{3} \sum_{j=1}^{3} \varphi_{i} \ln \frac{y_{i}}{A} T+\sum_{i=1}^{3} \sum_{j=1}^{3} \vartheta_{i} \ln \frac{w_{i}}{w_{3}} T \\
& +\sum_{i=1}^{3} \sum_{j=1}^{3} \theta_{i j} \ln \frac{y_{i}}{A} \ln R+\sum_{i=1}^{3} \sum_{j=1}^{3} \mu_{i j} \ln \frac{w_{i}}{w_{3}} \ln R+\sum_{i=1}^{3} \sum_{j=1}^{3} \pi_{i j} T \ln R \\
& -\ln u_{i t}+\ln v_{i t}
\end{aligned}
$$

2) Data and selection of indicators

This paper choose 15 commercial banks in China as samples, which include five state-owned banks and ten joint-stock commercial banks whose information disclosure are standard and financial information are accessible. The data sources are annual reports of these commercial banks and Bank scope database. 
We choose 2007-2016 as the observation period, the main reasons are that during this period, internet finance has undergone tremendous development and the external environment of the commercial banks has undergone major changes. There are totally 150 sample observations, for some missing observations, we use interpolation to calculate.

In order to conduct a SFA, inputs and outputs need to be defined. Four main approaches (intermediation, production, asset and profit approach) have been developed to define the input-output relationship in financial institution behavior. Based on previous research experience, this paper selects six input and output indicators. The input indicators are the price of loanable funds, labor price and fixed asset price. The output indicators are the total loan, interest income and non-interest income. The specific meanings and calculation method of each indicator are as Table 1.

\subsection{Empirical Results and Analysis}

For empirical analysis, we used Frontier 4.1 software to measure the profit efficiency of 15 commercial banks. The empirical results are as Table 2 and Figure 1.

The average efficiency of state-owned banks and joint-stock banks is weighted by their total assets. Figure 1 and Table 2 shows that the average efficiency of state-owned banks is higher than that of joint-stock banks, while the average

Table1. Input and output indicators.

\begin{tabular}{|c|c|c|c|}
\hline & $\begin{array}{l}\text { Variable } \\
\text { code }\end{array}$ & variable name & Calculation method \\
\hline & PTA & Pretax profit & From the income statements \\
\hline $\begin{array}{l}\text { Explained } \\
\text { Variable }\end{array}$ & $\mathrm{TC}$ & Total cost & $\begin{array}{l}\text { Operating expenses }=\text { operating taxes and additional } \\
+ \text { business management fees }+ \text { assets devaluation }+ \\
\text { other business costs }\end{array}$ \\
\hline \multirow{3}{*}{$\begin{array}{l}\text { Input } \\
\text { indicators }\end{array}$} & $w_{1}$ & $\begin{array}{l}\text { Loanable funds } \\
\text { price }\end{array}$ & $\begin{array}{l}\text { Bank interest expense/total interest-bearing liabilities, } \\
\text { total interest-bearing liabilities include bank deposits, } \\
\text { interbank and other financial institutions deposit and } \\
\text { withdrawals, debt securities, and repurchase } \\
\text { agreement }\end{array}$ \\
\hline & $w_{2}$ & Labor price & Staff cost/staff number \\
\hline & $W_{3}$ & $\begin{array}{l}\text { Fixed assets } \\
\text { price }\end{array}$ & $\begin{array}{l}\text { Depreciation accrued this year/the net value of fixed } \\
\text { assets }\end{array}$ \\
\hline \multirow{3}{*}{$\begin{array}{l}\text { Output } \\
\text { indicators }\end{array}$} & $y_{1}$ & Total loan & $\begin{array}{l}\text { Short-term, medium-term and long-term loans and } \\
\text { other loans, after deduction of loan loss reserves }\end{array}$ \\
\hline & $y_{2}$ & Interest income & $\begin{array}{l}\text { Interest income from the loans, deposits with } \\
\text { interbank and central bank, lending funds and buying } \\
\text { securities and return sale }\end{array}$ \\
\hline & $y_{3}$ & $\begin{array}{l}\text { Non-interest } \\
\text { income }\end{array}$ & $\begin{array}{l}\text { Including fees and commissions net income, other } \\
\text { business income, investment income, etc }\end{array}$ \\
\hline Risk factor & $\mathrm{R}$ & $\begin{array}{l}\text { Loan loss } \\
\text { reserves }\end{array}$ & The balance of loan loss reserve \\
\hline
\end{tabular}


Table 2. Efficiency of 15 Chinese commercial banks from 2007 to 2016.

\begin{tabular}{|c|c|c|c|c|c|c|c|c|c|c|}
\hline BANK & 2007 & 2008 & 2009 & 2010 & 2011 & 2012 & 2013 & 2014 & 2015 & 2016 \\
\hline CITIC & 0.70 & 0.77 & 0.64 & 0.85 & 0.79 & 0.66 & 0.75 & 0.58 & 0.55 & 0.53 \\
\hline $\mathrm{BOC}$ & 1.00 & 0.80 & 0.98 & 0.90 & 0.79 & 0.67 & 0.74 & 0.99 & 0.83 & 0.82 \\
\hline BOCOM & 0.75 & 0.81 & 0.57 & 0.56 & 0.59 & 0.56 & 0.53 & 0.48 & 0.50 & 0.59 \\
\hline CEB & 0.54 & 0.45 & 0.58 & 0.66 & 0.67 & 0.65 & 0.61 & 0.59 & 0.61 & 0.53 \\
\hline CIB & 0.55 & 0.62 & 0.55 & 0.64 & 0.77 & 0.94 & 1.00 & 0.89 & 0.97 & 0.87 \\
\hline $\mathrm{ABC}$ & 0.58 & 0.47 & 0.57 & 0.85 & 0.92 & 0.84 & 0.84 & 0.82 & 0.67 & 0.65 \\
\hline HXB & 0.57 & 0.30 & 0.32 & 0.38 & 0.53 & 0.52 & 0.57 & 0.63 & 0.63 & 0.59 \\
\hline ICBC & 0.83 & 0.90 & 0.83 & 0.98 & 0.98 & 0.88 & 0.84 & 0.80 & 0.70 & 0.77 \\
\hline Ping An & 0.98 & 0.12 & 0.54 & 0.55 & 0.51 & 0.52 & 0.62 & 0.77 & 0.75 & 0.76 \\
\hline CGB & 0.42 & 1.00 & 0.87 & 0.92 & 0.99 & 0.76 & 0.70 & 0.99 & 1.00 & 0.98 \\
\hline CCB & 1.00 & 0.97 & 0.83 & 1.00 & 0.99 & 0.87 & 0.87 & 0.84 & 0.51 & 0.62 \\
\hline Heng Feng & 0.34 & 0.35 & 0.42 & 0.59 & 0.68 & 0.62 & 0.85 & 0.58 & 0.58 & 0.69 \\
\hline $\mathrm{CMB}$ & 0.86 & 0.85 & 0.42 & 0.77 & 0.98 & 0.93 & 0.86 & 0.72 & 0.84 & 0.98 \\
\hline $\mathrm{CMBC}$ & 0.38 & 0.41 & 0.52 & 0.92 & 0.96 & 0.91 & 0.92 & 0.80 & 0.80 & 0.75 \\
\hline SPDB & 0.63 & 0.81 & 0.58 & 0.72 & 0.76 & 0.69 & 0.69 & 0.70 & 0.78 & 0.77 \\
\hline $\begin{array}{l}\text { State-owned } \\
\text { banks }\end{array}$ & 0.85 & 0.80 & 0.79 & 0.91 & 0.89 & 0.80 & 0.80 & 0.83 & 0.66 & 0.70 \\
\hline $\begin{array}{l}\text { Joint-stock } \\
\text { banks }\end{array}$ & 0.55 & 0.76 & 0.65 & 0.79 & 0.85 & 0.76 & 0.75 & 0.81 & 0.84 & 0.82 \\
\hline All banks & 0.77 & 0.79 & 0.75 & 0.87 & 0.88 & 0.79 & 0.78 & 0.82 & 0.73 & 0.75 \\
\hline
\end{tabular}

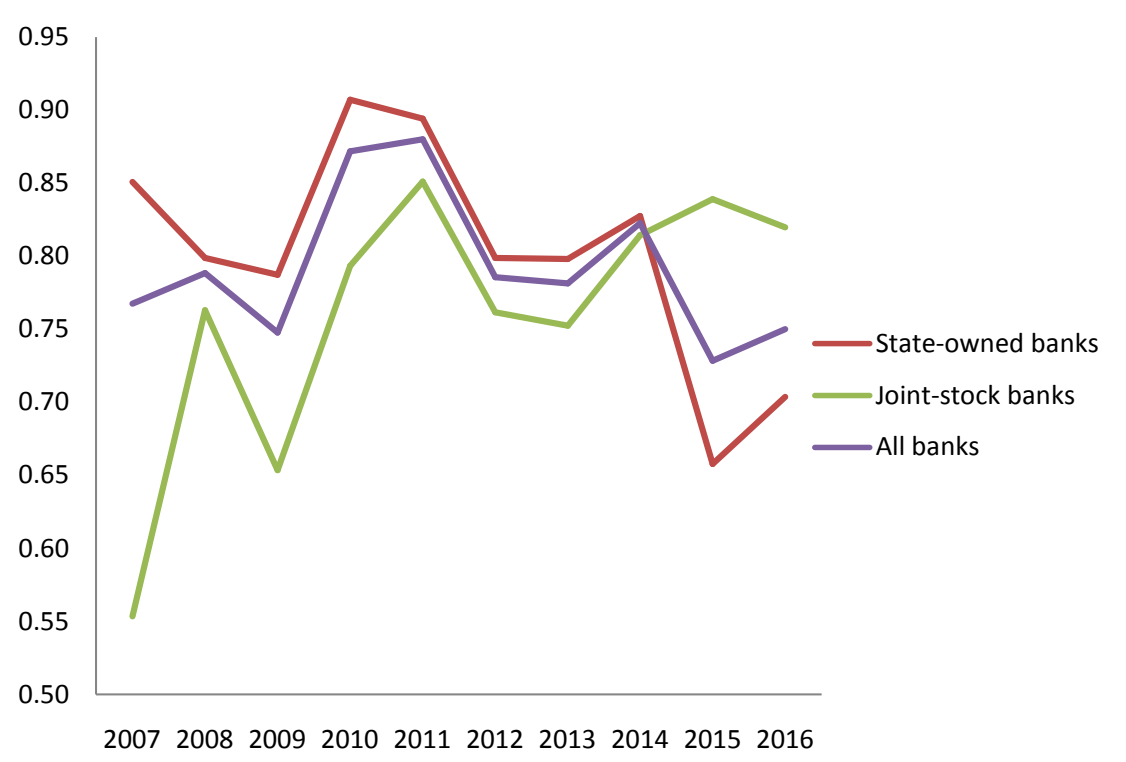

Figure 1. The dynamic change of average efficiency of 15 Chinese commercial banks.

efficiency of joint-stock banks has significantly exceeded state-owned banks since 2015. All banks' efficiency fluctuated greatly from 2007 to 2016, where, the 
efficiency of state-owned banks is in decline, the efficiency of joint-stock banks is on the rise. The efficiency of state-owned banks and joint-stock banks show same fluctuation tendency from 2008 to 2014, but a large gap exists between them in 2015.

The efficiency of all banks declined from 2008 to 2009. The main reason for this is that the U.S. subprime mortgage crisis broke out in 2008, then spread rapidly from the developed world into developing nations as a global financial crisis. Global financial markets and international trade have been hit in different ways, which directly caused the exports of China fallen sharply. On the while, The business development and operating efficiency of Chinese commercial banks were also affected to some extent with the rate of economic growth of China dropped sharply. After the outbreak of the global financial crisis, in order to stabilize the domestic financial system, the government strengthened the regulation of Chinese banking system. They proposed new capital adequacy targets of $10 \%$ and $11 \%$ respectively for small and medium banks and large banks at the end of 2008, which influenced the profit growth of domestic banks directly. In the years which followed, the impact of the financial crisis was gradually eliminated, and the efficiency of all banks rised gradually. China's GDP growth rate reached $18 \%$ in 2010 and 2011, which created huge space for the growth of the banking business performance. Meanwhile, commercial banks have successively entered into shareholding reform, improve the corporate governance structure by listing, introducing strategic investors and improving capital structure.

It is worth noting that the average efficiency of state-owned commercial banks fell to 0.66 in 2015, while the average efficiency of joint-stock banks is 0.84 . The main reason for this is that domestic economic growth slowed down and the commercial banks' core capital adequacy ratio were raised to 6 percent by Basel III, which hindered the growth of commercial banks' profits.

\section{Empirical Study on Influence Factors of Bank Efficiency}

\subsection{Modeling, Data and Selection of Indicators}

This section focuses on the influence factors of the efficiency of commercial banks, mainly including banks' own factors, industry factors and Internet development degree.

The model is set as follows:

$$
\begin{aligned}
E F F_{i t}= & \beta_{0}+\beta_{1} * N L R+\beta_{2} * B S+\beta_{3} * P R S+\beta_{4} * M S \\
& +\beta_{5} * T P P+\beta_{6} * G O P+\varepsilon_{i t}
\end{aligned}
$$

where $E f f_{i t}$ represents the efficiency of bank " $\vec{i}$ " in year " $\vec{t}$, the meanings of influencing indicators are as Table 3.

The research samples are 15 commercial banks in China from 2007 to 2016, and the data mainly comes from the annual reports of these banks, other data comes from China Statistical Yearbook, statistical data of China banking regulatory commission and Online Lending House.

Table 4 shows that the average non-performing loan ratio of commercial 
Table 3. Main influencing factors of bank efficiency.

\begin{tabular}{|c|c|c|}
\hline Variable code & variable name & Calculation method \\
\hline NLR & Non-performing loan ratio & Non-performing loan/total loans \\
\hline BS & Bank size & The logarithm of total assets \\
\hline PRS & Property right structure & $\begin{array}{l}\text { " } 1 \text { " represents state-owned commercial banks, } \\
\text { " } 0 \text { " represents joint-stock commercial banks }\end{array}$ \\
\hline MS & Market structure & $\begin{array}{l}\text { The top } 4 \text { loans in banking industry/Total } \\
\text { loans in banking industry }\end{array}$ \\
\hline TPP & Third-party payment & The logarithm of the third-party payment \\
\hline GOP & $\begin{array}{l}\text { The growth rate of } \mathrm{P} 2 \mathrm{P} \\
\text { trading amount }\end{array}$ & - \\
\hline
\end{tabular}

Table 4. Statistical description of explaining variables.

\begin{tabular}{ccccc}
\hline & Mean & Maximum & Minimum & Variance \\
\hline Non-performing loan ratio (\%) & 1.49 & 23.570 & 0.380 & 1.97 \\
Bank size & 15.07 & 16.99 & 11.58 & 1.14 \\
Property right structure & - & - & - & - \\
Market structure & 0.14 & 0.16 & 0.12 & 0.01 \\
Third-party payment & 15.54 & 17.87 & 11.52 & 1.95 \\
The growth rate of P2P trading amount & 257.05 & 583.87 & 110.08 & 132.58 \\
\hline
\end{tabular}

banks between 2007 and 2016 was $1.49 \%$, the variance of commercial banks from 2007 to 2016 is $1.97 \%$. The non-performing loan ratio reflects the asset quality of the bank. The data above shows that the asset quality of different banks varies greatly from 2007 to 2016. We take the logarithm of total asset of banks to represent the bank size, the mean of banks' size is 15.07 . The maximum of bank size comes from ICBC, which is 16.99 in 2016, the minimum of bank size comes from Heng Feng Bank, which is 11.58 in 2007. The property right structure is a dummy variable, where, "1" represents state-owned commercial banks and "0" represents joint-stock commercial banks. The market structure measures the loan concentration of Chinese banking industry and reflects the competition and monopoly of the banking industry. The loan concentration is largest in 2007, and smallest in 2016, which shows that the monopoly degree of China's banking industry is decreasing year by year, and the market competition among banks is increasing year by year. We take the logarithm of the third-party payment and the growth rate of $\mathrm{P} 2 \mathrm{P}$ trading amount to measure the development of Internet finance. The Third-party payment is between 11.52 and 17.87, and the growth rate of $\mathrm{P} 2 \mathrm{P}$ trading amount is between $110.08 \%$ and $583.87 \%$.

\subsection{Empirical Results and Analysis}

We used Frontier 4.1 software to measure the efficiency of 15 commercial banks. The empirical results are as follows: 
In this section, we estimate the parameter values of efficiency influencing factors by using the special program Frontier 4.1 of Collie (1996) when measuring the efficiency of banks. The parameter estimate of influencing factors is as Table 5.

Table 5 shows that the likelihood ratio of the model is 107.91, the log likelihood function of the model is 111.54 and the $\gamma$ is 0.99 , which explain that this estimation model is effective. According to each parameter estimate, the following conclusions can be obtained.

1) The regression coefficient of non-performing loan ratio is -5.46 , significant at $1 \%$. There is a significant negative correlation between the non-performing loan ratio and the efficiency of commercial banks. The higher the non-performing loan ratio is, the worse the bank's asset quality is and the lower the bank's efficiency is.

2) The regression coefficient of asset size was 0.12 , significant at $5 \%$. Banks' asset size is positively correlated with the efficiency of the commercial bank. The larger the banks' asset size is, the higher the bank's efficiency is. The efficiency of commercial banks we measure in Section 3 shows that the asset size of state-owned banks is larger than joint-stock banks and the efficiency of state-owned banks is significantly higher than joint-stock banks. Our parameter estimate is consistent with the actual situation of Chinese commercial bank efficiency.

3) The regression coefficient of property right structure is negative, significant at $1 \%$, which shows the state-owned property right will impact on bank efficiency negatively. Comparing the trends of state-owned banks' efficiency and joint-stock banks' efficiency, we can find that the joint-stock banks are showing obvious management advantages, and the efficiency of them is catching up with the state-owned banks gradually.

4) The regression coefficient of market structure is -1.82 , significant at $10 \%$,

Table 5. The parameter estimate of influencing factors of bank efficiency.

\begin{tabular}{|c|c|c|}
\hline Variable & coefficient & t-value \\
\hline cons & 2.72 & $3.89^{* * *}$ \\
\hline NLR & -5.45 & $-5.06^{* * *}$ \\
\hline BS & 0.12 & $2.01^{* *}$ \\
\hline PRS & -3.95 & $-3.18^{* * *}$ \\
\hline MS & -1.82 & $-1.82^{*}$ \\
\hline TPP & -0.26 & $-10.11^{\star * *}$ \\
\hline GOP & -0.02 & -0.91 \\
\hline gamma & \multicolumn{2}{|c|}{0.99} \\
\hline log likelihood function & \multicolumn{2}{|c|}{111.53} \\
\hline LR test & \multicolumn{2}{|c|}{107.90} \\
\hline
\end{tabular}

Notes: ${ }^{*}{ }^{* *},{ }^{* *}$ indicate significant at $10 \%, 5 \%, 1 \%$, respectively. 
which shows that the higher the loan concentration in the banking industry is, the lower the efficiency level of commercial banks is. There is a significant negative correlation between market monopoly and the banks' efficiency.

5) The regression coefficient of the third-party payment is -0.26 , significant at $1 \%$. Third-party payment is negatively correlated with the banks' efficiency, the larger the third-party payment is, the lower the banks' efficiency is. The regression coefficient of the growth rate of $\mathrm{P} 2 \mathrm{P}$ trading amount is negative. It also shows negative correlation with the banks' efficiency though not significant. On the whole, the development of Internet finance will reduce the efficiency of commercial banks.

\section{Conclusions and Recommendations}

\subsection{Research Conclusions}

From the analysis of commercial banks' efficiency measurement results, we can see that the efficiency of commercial banks in China are on the rise which accords with the development of Chinese banking industry in the past 10 years. The efficiency of commercial banks is pro-cyclical, and is closely related to the macro-economic development. There is a certain gap between the efficiency of domestic commercial banks, and the efficiency of state-owned banks is higher than that of joint-stock banks.

From the analysis of influencing factors of bank efficiency, we can see that the efficiency of commercial banks in China has significant correlation with the non-performing loan ratio, asset size, property right structure, market structure and Internet financial. The positive correlation between asset size and bank efficiency shows that there is still scale effect in Chinese banking industry. The negative correlation between non-performing loan ratio and bank efficiency shows non-performing loan will hurt the bank's operating performance, which is consistent with the conclusions of most scholars. The property right of commercial banks and the market structure is negative correlated with the efficiency of commercial banks. State-owned property rights will damage the efficiency of banks. The negative correlation between Internet finance development and bank efficiency shows that the new payoff pattern and financing pattern created by Internet finance still pose threats on traditional commercial banks.

\subsection{Suggestions}

In view of non-performing loans and credit risk management, commercial banks should strengthen asset quality management and improve the level of credit supervision. Commercial banks should continue to construct its comprehensive risk management system, continuously strengthen risk management techniques and management methods, and improve risk pre-judgment and dynamic control capabilities. The regulators should focus on the rebound of non-performing loans and the deterioration of loan qualities, strengthen the assessment of non-performing loans, regularly analyze major regulatory indicators, and pay 
close attention to key credit risks caused by industrial structural adjustment and excess capacity of manufacturing industry.

In order to broaden the international market and improve safety and profitability of Chinese banking system, commercial banks should promote the reform of property rights reform, increase the financial openness, actively introduce strategic investors and improve corporate governance mechanism. To promote the diversification reforms of the market structure and create a good market competition atmosphere, the government should actively support the development of small and medium banks and broaden the criteria for the market access. Meanwhile, regulators should strengthen the banking market legal system, maintain a good market order, provide commercial banks with a positive, fair and efficient market competition environment, and promote the sustainable development and stable management of the banking industry.

Commercial banks should transform their traditional business pattern and create new profit growth points. Firstly, commercial banks should speed up innovation and transform, build new competitive development advantages, integrate the Internet with traditional businesses, and vigorously develop their own Internet finance business. Secondly, commercial banks should tap their own advantages, such as strong capital, abundant customer resources and development experience, adequate infrastructure and widely distributed outlets, high social recognition and customer stickiness, and improve the comprehensive service system to meet the all-dimensional financial needs of customers.

\subsection{Contributions and Deficiencies}

Based on the Finance and Economics Theory, this paper studies the efficiency of commercial banks through the mathematical economics methods, finds that there is a negative correlation between Internet Finance and bank efficiency through empirical research.

Due to limitations of the author's knowledge theory system, research environment and research scope, there are still some deficiencies in this article, which are as follows: 1) the main data come from commercial bank annual report, considering the integrity of the data, this paper only select state-owned Banks and joint-stock commercial Banks whose information disclosure are standard as research samples. 2) Scholars have no fixed standard for input and output indicators, and adding different factors to the inefficiency item will cause slight differences in bank efficiency. This paper only selects some influencing factors, and within the scope of the study, made a reasonable explanation of these influencing factors.

\section{References}

[1] Řepková, I. (2015) Banking Efficiency Determinants in the Czech Banking Sector. Procedia Economics and Finance, 23, 191-196.

[2] Tan, Y. and Floros, C. (2013) Risk, Capital and Efficiency in Chinese Banking. Journal of International Financial Markets, Institutions \& Money, 26, 378-393. 
[3] Mosko, A. and Bozdo, A. (2016) Modeling the Relationship between Bank Efficiency, Capital and Risk in Albanian Banking System. Procedia Economics and Finance, 39, 319-327.

[4] Fiordelisi, F., Marques-Ibanez, D. and Molyneux, P. (2011) Efficiency and Risk in European Banking. Journal of Banking \& Finance, 35, 1315-1326. https://doi.org/10.1016/j.jbankfin.2010.10.005

[5] Delis, M., Iosifidi, M. and Tsionas, M.G. (2017) Endogenous Bank Risk and Efficiency. European Journal of Operational Research, 260, 376-387.

[6] Wang, C. and Zou, P.F. (2006) Study on X-Efficiency of Chinese Commercial Banks Based on Capital Structure and Risk. Management World, 11, 6-12.

[7] Cheng, M.Y. and Zhao, H. (2011) Analysis of Influence of Market Power on Bank Efficiency. The Journal of Quantitative \& Technical Economics, 10, 78-91.

[8] Liu, R.X., Lv, X. and Luo, Y. (2016) The Measurement of China's Commercial Banks' Efficiency under the Restriction of Bad Loans-Based on the Two-Phase DEA Model. Journal of Nanjing Audit University, 6, 41-50.

[9] He, Y. (2014) Analysis of Cost Efficiency and Influencing Factors of China's Banking Industry: A Study Based on Stochastic Frontier Approach. Central China Normal University Journal of Postgraduates, 21, No. 12.

[10] Zhu, J.C. (2013) Research on the Background, Current situation and the Trend of Internet Finance. Rural Finance Research, 10, 5-8.

[11] Qiu, F. (2013) Internet Financial Shock and Commercial Bank Response. Financial Accounting, 11, 45-49.

[12] Zhang, M. (2014) Internet Finance and Traditional Finance. China Policy Review, 2, 46-49.

[13] Battese, G.E. and Coelli, T.J. (1995) A Model for Technical Inefficiency Effects in a Stochastic Frontier Production Function for Panel Data. Empirical Economics, 20, 325-332. https://doi.org/10.1007/BF01205442

[14] Yao, S.J., Jiang, C.X. and Feng, G.F. (2011) The Reform and Efficiency of Chinese Banking: 1995-2008. Economic Research Journal, 8, 4-14. 